\title{
Renal Function Loss After Cryoablation of Small Renal Masses in Solitary Kidneys: European Registry for Renal Cryoablation Multi-Institutional Study
}

\author{
Seshadri Sriprasad, ${ }^{1}$ Mohammed Aldiwani,, Shiv Pandian,, Tommy K. Nielsen, ${ }^{1}$ \\ Mohamed Ismail,, ${ }^{3,4}$ Neil J. Barber, ${ }^{5}$ Giovanni Lughezzani,, Alessandro Larcher, \\ Brunolf W. Lagerveld, ${ }^{7}$ and Francis X. Keeley, $\mathrm{Jr}^{3}$
}

\begin{abstract}
Objectives: To estimate and quantify the loss of kidney function in solitary kidneys with small renal masses (SRMs) after laparoscopy-assisted renal cryoablation (LARC), from the European Registry for Renal Cryoablation (EuRECA) database.

Patients and Methods: Of the 808 patients from eight European centers in the database, 102 patients had SRMs in solitary kidneys. Patient demographics, body mass index (BMI), American Society of Anesthesiologists (ASA) grade, Charlson comorbidity index, and tumor characteristics including nephrometry (PADUA) score where available were collected. Renal function data in the form of estimated glomerular filtration rate (eGFR) and chronic kidney disease (CKD) stratification both preoperatively and at 3 months postoperatively were collected.

Results: The median (interquartile range [IQR]) age was 67 (59-81) years, the median (IQR) BMI was 26 (23.928.9) $\mathrm{kg} / \mathrm{m}^{2}$, and the median (IQR) ASA score was 2 (2-3). The median Charlson score was 4 (range: 0-10). The median (IQR) tumor size in cross-sectional imaging was $26(19-38) \mathrm{mm}$. The follow-up data were available for 72 patients with a median follow-up for this group of 38 (range: 10-132) months. The mean preoperative eGFR was $55.0 \mathrm{~mL} / \mathrm{minute} / 1.73 \mathrm{~m}^{2}$ (standard deviation $[\mathrm{SD}]=18.1$ ), and the mean postoperative eGFR was $51.8 \mathrm{~mL} / \mathrm{minute} /$ $1.73 \mathrm{~m}^{2}(\mathrm{SD}=18.8)$. The change was $-3.1 \mathrm{~mL} /$ minute $/ 1.73 \mathrm{~m}^{2}$ (95\% confidence interval -5.2 to -1.0$)$ units, which was statistically significant $(p=0.004)$. The change in the CKD stages comparing before and after LARC was not significant (paired two-tailed $t$-test, $p=0.06$ ). Critically, the decrease in the eGFR did not translate to any significant adverse outcome and zero patients required dialysis.

Conclusion: To the best of our knowledge, this is the largest study of renal function after LARC in SRMs in solitary kidneys. Cryotherapy in this imperative situation is safe, carries clinically insignificant reduction in renal function, therefore providing an option to minimize the risk of developing renal failure necessitating dialysis.
\end{abstract}

Keywords: renal cryoablation, solitary kidney, renal cell carcinoma, nephron sparing surgery, partial nephrectomy

\section{Introduction}

T HE INCIDENCE OF small renal masses (SRMs) $\leq 4 \mathrm{~cm}$, stage $\mathrm{T} 1 \mathrm{a}$, is increasing due to the wider use of diagnostic imaging. The European and American management guidelines currently recommend nephron sparing surgery, with partial nephrectomy (PN) being the gold standard for the treatment of SRMs. ${ }^{1,2}$ Nephron sparing surgery offers oncologic control comparable to that provided by radical nephrectomy with better preservation of the renal function than the latter. ${ }^{3,4}$ However, in patients with two healthy functioning kidneys, the contralateral kidney does compensate

\footnotetext{
${ }^{1}$ Department of Urology, Darent Valley Hospital, Dartford, United Kingdom.

${ }^{2}$ Department of Urology, Aarhus University Hospital, Aarhus, Denmark.

${ }^{3}$ Bristol Urological Institute, North Bristol NHS Trust, Bristol, United Kingdom.

${ }_{5}^{4}$ Department of Urology, Portsmouth Hospitals NHS trust, Portsmouth, United Kingdom.

${ }^{5}$ Department of Urology, Frimley Park Hospital, Camberley, United Kingdom.

${ }^{6}$ Department of Urology, San Raffaele Hospital, Milan, Italy.

${ }^{7}$ Department of Urology, Onze Lieve Vrouwe Gasthuis, Amsterdam, the Netherlands.
} 
and therefore to estimate true loss of function is difficult. Open, laparoscopic, and robotic PN carry the risk of significant perioperative complications with a potential for significant nephron loss in single kidney. ${ }^{5}$ Preservation of renal function in a single kidney is imperative to prevent the need for renal replacement therapy.

In the last decade, the use of ablative techniques such as cryotherapy has started to increase in selected patients with an acceptable intermediate-term oncologic outcome. ${ }^{6}$ More importantly, after cryotherapy in T1a tumors in solitary kidneys, the renal function seems to be preserved in preliminary studies with small numbers. ${ }^{7-9}$

The present study was initiated by the European Registry for Renal Cryoablation (EuRECA), with the aim of investigating renal function outcomes after laparoscopy-assisted renal cryoablation (LARC) in SRMs in solitary kidneys from a large multi-institutional cohort.

\section{Patients and Methods}

The EuRECA database consisted of 808 patients who underwent LARC of SRMs between 2005 and 2016 in eight different European centers. Of these patients, 102 had SRMs in solitary kidneys and they constituted the study cohort. Each of the contributing centers used their own patient selection criteria and preferred surgical approach for the treatment. The cryoablation treatment session consisted of two freezing cycles $(2 \times 10$ minutes each) using Galil Medical $^{\circledR}$ (Arden Hills, MN) cryosystem and cryoprobes. In each freezing cycle, the temperature was pushed to at least $-40^{\circ} \mathrm{C}$, and two freezing cycles were separated by a passive thawing phase up to $0^{\circ} \mathrm{C}$.

\section{Aims of the study}

The primary objective was to estimate and quantify the loss of kidney function in solitary kidneys with SRMs after LARC and to examine whether any of these patients required any form of renal replacement therapy. Secondary objectives were to examine oncologic control and perioperative morbidity.

\section{Data management and statistical analysis}

After approval from each of the eight participating centers and their respective local scientific and/or ethical committees, treatment and follow-up data for the 102 patients with solitary kidneys were collected from prospectively maintained local databases and combined for retrospective analysis. The data collected included age, gender, body mass index (BMI), American Society of Anesthesiologists (ASA) score, Charlson comorbidity index, history of renal cancer, tumor size, tumor grade, biopsy outcome, "PADUA" nephrometry score, postoperative complication, and blood transfusion requirement. In addition, the follow-up data, recurrence, survival, and oncologic outcome were also collected.

Prospectively, values of estimated glomerular filtration rate (eGFR) were recorded for all these patients preoperatively and at 3 months postoperatively after LARC. The preoperative and postoperative chronic kidney disease (CKD) grades were recorded as per the CKD classification shown in Table $1 .{ }^{10}$ Furthermore, we prospectively recorded
Table 1. Grading of Chronic Kidney Disease

\begin{tabular}{lc}
\hline$C K D$ & $e G F R\left(\mathrm{~mL} /\right.$ minute $\left./ 1.73 \mathrm{~m}^{2}\right)$ \\
\hline Grade I & $\geq 90$ \\
Grade II & $60-89$ \\
Grade IIIa & $45-59$ \\
Grade IIIb & $30-44$ \\
Grade IV & $15-29$ \\
Grade V & $\leq 14$ \\
\hline
\end{tabular}

$\mathrm{CKD}=$ chronic kidney disease; $\mathrm{eGFR}=$ estimated glomerular filtration rate.

whether patients needed any form of renal replacement therapy (peritoneal or hemodialysis) during the follow-up.

The eGFR values and the CKD grade in this group of patients showed a normal distribution at each time point, and the change in eGFR values and the CKD grade was also normally distributed. Because of this, the parametric statistical, paired $t$-test was used to compare the preoperative and postoperative eGFR and the CKD values.

\section{Results}

The study included 102 patients with solitary kidneys, with $95(93.1 \%)$ having a previous nephrectomy for renal cancer. The rest had a functionally single kidney. A total of four patients in our series were undergoing a re-ablation. There were 74 males and 28 females, with a median (interquartile range [IQR]) age of 67 (59-81) years, the median (IQR) BMI was $26(23.9-28.9) \mathrm{kg} / \mathrm{m}^{2}$, and the median (IQR) ASA score was 2 (2-3). The median Charlson score was 4 (range: 0-10). The median (IQR) tumor size in cross-sectional imaging was 26 (19-38) mm. The "PADUA" nephrometry score was available for 48 patients, and the median score was 8 (range: 6-12). The transperitoneal laparoscopic approach was utilized for cryotherapy in 70 patients and the retroperitoneal approach in 32 patients. None of the patients in this cohort required blood transfusion. There were 16 complications. Twelve of them had a Clavien-Dindo grade II and three patients had a grade III complication. One patient required intensive care management for a prolonged ileus, making it a grade IVa. There was no perioperative death in the first 30 days of cryotherapy. The median hospital stay was 2 (range: 1-10) days.

The postoperative histopathology confirmed renal carcinoma with the following subtypes: clear cell tumor in 85 patients, papillary differentiation in 13 patients, and chromophobe tumor in 4 patients. There were four patients with local recurrence and four patients with treatment failure/incomplete ablation. The long-term follow-up data were available for 72 patients. The median follow-up for this group was 38 (range: 10-132) months. The overall survival was $87.5 \%$, the cancer-specific survival was $93 \%$, and the disease-free survival was $90.3 \%$. Since the majority of patients had undergone a contralateral nephrectomy for renal cancer, the source of metastatic disease cannot be definitively established.

The preoperative and postoperative eGFR values were compared, and the analyzed results are summarized in Table 2. Patient characteristics are summarized in Table 3. 
Table 2. Preoperative and Postoperative EGFR (ML/MiNUTE/1.73 $\mathrm{M}^{2}$ )

\begin{tabular}{lcccc}
\hline & & $e G F R$, & $e G F R$ change, & \\
Time point & $\mathrm{n}$ & mean $(S D)$ & mean $(95 \% C I)$ & $\mathrm{p}$ \\
\hline
\end{tabular}

$\begin{array}{lllll}\text { Preoperatively } & 102 & 55.0(18.1) & - & \\ \text { Postoperatively } & 102 & 51.8(18.8) & 3.1(1.0-5.2) & 0.004\end{array}$
(3 months)

${ }^{\text {a }}$ Change calculated by subtracting the postoperative eGFR value from the preoperative eGFR value.

$\mathrm{CI}=$ confidence interval $\mathrm{SD}=$ standard deviation .

The analyzed results indicate that there is a statistically significant change between the preoperative and postoperative eGFR values. Their mean reduction in eGFR values postoperatively is $3.1 \mathrm{U}$, amounting to $5 \%-6 \%$ loss of renal function. While this result is of statistical significance $(p=0.004)$ (Table 2), it did not translate into clinical significance. This did not appear to vary significantly according to tumor location $(-2.45 \mathrm{U}$ for middle tumors $v s$. -1.48 for superior/inferior tumors; $p=0.71$ ) and renal sinus involvement $(-5.19$ involved $v s$. -0.81 uninvolved renal sinus; $p=0.23$ ). The minor numerical loss of eGFR did not lead to any significant adverse clinical outcome in any of

Table 3. Summary of Patient AND TUMOR CHARACTERISTICS

\begin{tabular}{|c|c|c|}
\hline Characteristic & $\mathrm{n}$ & $\begin{array}{c}\text { Mean change } \\
\text { in eGFR } \\
\left(\mathrm{mL} / \text { minute } / 1.73 \mathrm{~m}^{2}\right)\end{array}$ \\
\hline $\begin{array}{l}\text { Total patients } \\
N\end{array}$ & 102 & \\
\hline $\begin{array}{l}\text { Gender } \\
\text { Male } \\
\text { Female }\end{array}$ & $\begin{array}{l}74 \\
28\end{array}$ & \\
\hline $\begin{array}{l}\text { Tumor size, } \mathrm{cm} \\
\quad 4 \text { or less } \\
>4\end{array}$ & $\begin{array}{r}97 \\
5\end{array}$ & \\
\hline $\begin{array}{l}\text { Previous nephrectomy for } \\
\text { Yes } \\
\text { No }\end{array}$ & $\begin{array}{l}\text { cer } \\
95 \\
14\end{array}$ & \\
\hline $\begin{array}{l}\text { Histology } \\
\text { Clear cell } \\
\text { Papillary differentiation } \\
\text { Chromophobe }\end{array}$ & $\begin{array}{r}85 \\
13 \\
4\end{array}$ & \\
\hline $\begin{array}{l}\text { Age, years } \\
<60 \\
60-69 \\
>70\end{array}$ & $\begin{array}{l}30 \\
43 \\
29\end{array}$ & $\begin{array}{l}-3.23 \\
-2.65 \\
-4.07\end{array}$ \\
\hline $\begin{array}{l}\text { Renal sinus involvement (d } \\
\text { Involved } \\
\text { Not involved }\end{array}$ & $\begin{array}{c}\text { umen } \\
16 \\
31\end{array}$ & $\begin{array}{c}\text { for } 47 \text { patients) } \\
-5.19 \\
-0.81 \\
p=0.23^{\mathrm{a}}\end{array}$ \\
\hline $\begin{array}{l}\text { Tumor location (documente } \\
\text { Middle } \\
\text { Superior/inferior }\end{array}$ & $\begin{array}{r}\text { for } 75 \\
44 \\
31\end{array}$ & $\begin{array}{l}\text { atients) } \\
-2.45 \\
-1.48 \\
p=0.71^{\mathrm{a}}\end{array}$ \\
\hline
\end{tabular}

${ }^{\mathrm{a}}$ Two tailed unpaired $t$-test. the patients. The change in the CKD stages comparing before and after LARC did not reach statistical significance (paired two-tailed $t$-test, $p=0.057$, not significant [NS]). Most importantly, none of the patients needed any form of renal replacement therapy at any time after the surgery.

An illustration of the eGFR values at the two time points is shown in Figure 1.

The preoperative and postoperative eGFR values for the 102 individual patients are illustrated in Figure 2.

\section{Discussion}

Solitary kidney represents an imperative indication for nephron sparing treatment of SRMs. In PN, it is inevitable to subject the kidney to a period of ischemia to control the blood loss. Several studies have attempted to quantify the damage to renal function caused by PN due to warm ischemia time (WIT). The attempt to measure the impact of WIT on renal function is frequently masked by the compensation of the contralateral kidney. ${ }^{11}$

Several historic studies have demonstrated that renal damage was proportionate to WIT with a critical time of 20-25 minutes. ${ }^{5,12,13}$ Laparoscopic partial nephrectomy (LPN) replicates open principles; however, this is an advanced operation and learning curve is associated with longer WIT. ${ }^{5}$ Moreover, pre-existing CKD may also influence the renal functional outcome after ischemia for renal surgery. ${ }^{14}$

In a solitary kidney, WIT is of critical short- and long-term importance. Even in the most experienced of hands, of 362 patients undergoing PN in a solitary kidney, 19\% developed acute kidney injury, $17 \%$ developed new onset stage IV $\mathrm{CKD}$, and $2 \%$ required permanent dialysis. ${ }^{15}$ The median preoperative eGFR in this study was $61 \mathrm{~mL} /$ minute $/ 1.73 \mathrm{~m}^{2}$. These outcomes were significantly influenced by a longer WIT. Table 4 summarizes published functional outcomes from PN in solitary kidneys.

Another point to consider would be the loss in renal parenchymal volume (RPV), which is closely associated with long-term postoperative renal function. ${ }^{16}$ A published analysis by Woldu and associates ${ }^{17}$ concluded that ablative modalities including cryoablation and radiofrequency ablation

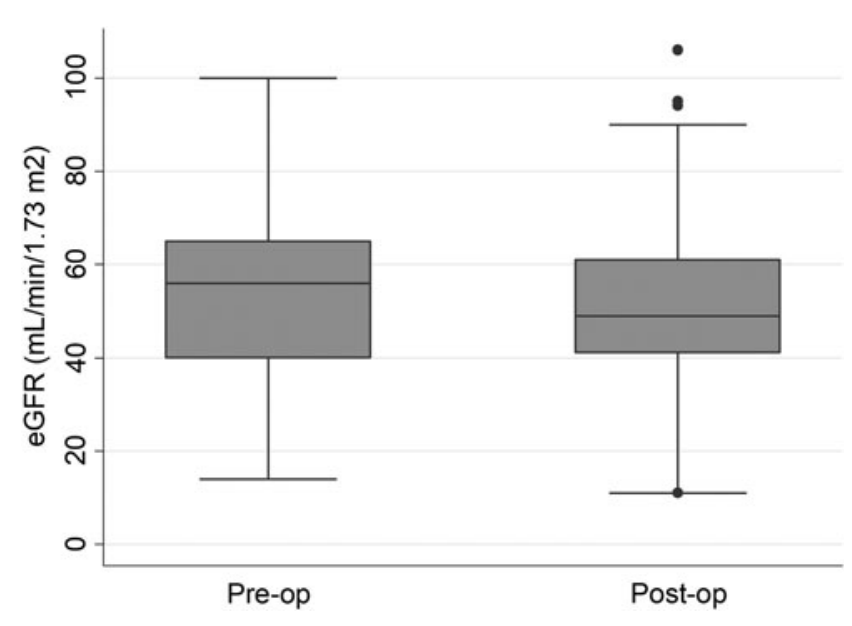

FIG. 1. Box plot illustration of preoperative and postoperative eGFR. eGFR = estimated glomerular filtration rate. 


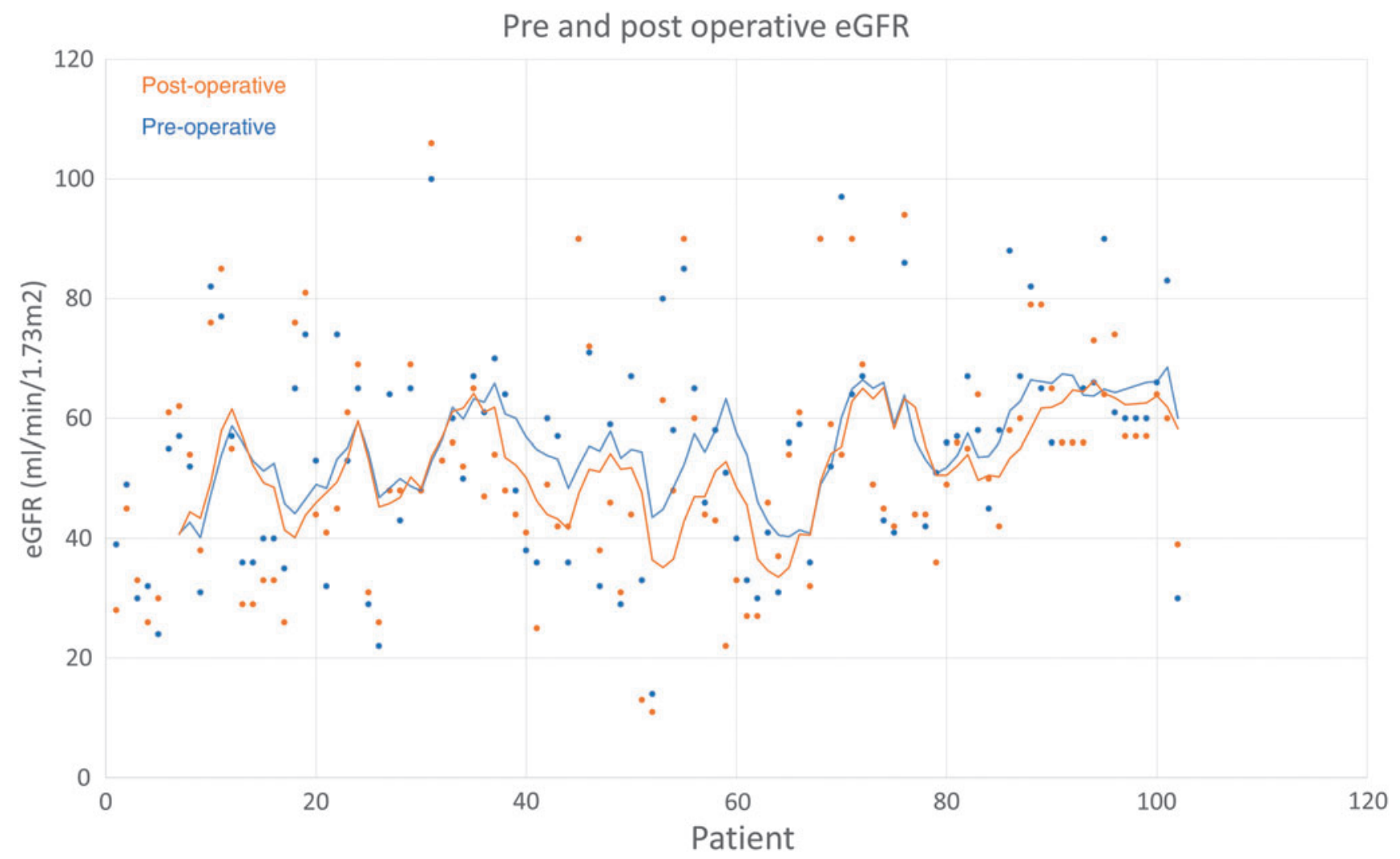

FIG. 2. Preoperative and postoperative eGFR values of all patients.

(RFA) were associated with less RPV loss compared with PN with its three modalities (open, laparoscopy-assisted, and robot-assisted).

Current European Association of Urology (EAU) guidelines suggest offering ablative techniques for SRMs in elderly/ comorbid patients only, and there are no specific guidelines in the context of solitary kidneys. Ablative modalities present an attractive alternative without subjecting a solitary kidney to any ischemia or risk of major hilar bleeding. Several pub- lished studies have compared PN with ablative therapies; however, these are all retrospective studies with crucial limitations related to patient selection bias. ${ }^{18}$ Within the available literature, there is a trend toward slightly lower rates of local recurrence and more superior oncologic outcomes with PN. ${ }^{19-23}$ This drawback must be balanced against the need for renal function preservation and patient comorbidity.

In the modern era, proponents of robotic partial nephrectomy (RPN) such as Emara and colleagues have reported

Table 4. Studies Evaluating Functional Outcomes of Partial Nephrectomy in Solitary Kidneys

\begin{tabular}{|c|c|c|}
\hline Author (year) & Included numbers & Functional outcome results \\
\hline Thompson $(2010)^{15}$ & $362 \mathrm{PN}$ (open and lap) & $\begin{array}{l}19 \% \text { AKI, } 17 \% \text { new CKD IV. } \\
2 \% \text { required permanent dialysis. }\end{array}$ \\
\hline Ghoneim $(2015)^{26}$ & $103 \mathrm{PN}$ & $\begin{array}{l}\text { Preoperative eGFR } 47 . \\
\text { Postoperative eGFR } 45 \text { (at } 3 \text { months). } \\
8 \text { AKI ( } 2.9 \% \text { temp dialysis). } \\
\text { Initial drop in renal function } \\
\text { then recovery plateau's at } 1 \text { month } \\
\text { postoperative regardless of ischemia time. }\end{array}$ \\
\hline La Rochelle $(2009)^{27}$ & $89 \mathrm{PN}$ & $\begin{array}{l}\text { eGFR drop for no ischemia, warm ischemia, } \\
\quad \text { cold ischemia of: } \\
\text { Early-29\%, } 37 \%, 45 \% \\
\text { Late-12\%, } 6 \%, 16 \% \\
4 \% \text { end-stage renal failure. }\end{array}$ \\
\hline Ching $(2013)^{28}$ & $\begin{array}{l}282 \mathrm{PN} \text { (open) } \\
5 \text { - and 10-year outcomes }\end{array}$ & $\begin{array}{l}\text { Mean eGFR stable at } 5 \text { years }(35.1) \text { and } 10 \text { years }(34.5) \text {. } \\
3 \% \text { on dialysis at } 5 \text { years. }\end{array}$ \\
\hline
\end{tabular}


Table 5. Comparative Retrospective Case Series Comparing Ablative Therapies to Partial Nephrectomy in Solitary Kidneys

\begin{tabular}{|c|c|c|}
\hline Author (year) & Study characteristics & Results \\
\hline Bhindi $(2018)^{29}$ & $\begin{array}{l}\text { Series with propensity-matched analysis. } \\
118 \text { solitary kidneys. } \\
54 \text { percutaneous cryoablation, } 64 \mathrm{PN} \text {. }\end{array}$ & $\begin{array}{l}\text { Smaller drop in eGFR at discharge } \\
\text { for PCA }(7 \% \text { vs. } 18 \%) \text { plateaued } \\
\text { by } 3 \text { months }(11 \% \text { vs. } 10 \%) \text {. } \\
\text { Need for dialysis not reported. } \\
\text { Propensity matched-no significant } \\
\text { difference at discharge and } 3 \text { months. } \\
\text { Fewer PCA complications. } \\
\text { No difference in oncologic outcomes. }\end{array}$ \\
\hline Mues $(2012)^{30}$ & $\begin{array}{l}205 \text { solitary kidneys. } \\
100 \text { PN, } 105 \text { ablations (not specified). }\end{array}$ & $\begin{array}{l}\text { No difference in eGFR. } \\
\text { Ablation: } \\
\text { fewer complication, } \\
\text { higher local recurrence }(6.7 \% \text { vs. } 3 \%) \text {. }\end{array}$ \\
\hline $\begin{array}{l}\text { Panumatrassamee } \\
(2013)^{31}\end{array}$ & $\begin{array}{l}62 \text { solitary kidneys. } \\
29 \text { cryo vs. } 33 \text { PN. } \\
\text { Nephrometry adjusted. }\end{array}$ & $\begin{array}{l}\text { eGFR change not significant between PN } \\
\text { and cryo when adjusted for tumor complexity. } \\
\text { Better perioperative outcome cryo. }\end{array}$ \\
\hline Turna $(2009)^{25}$ & $\begin{array}{l}101 \text { solitary kidneys. } \\
36 \text { LPN, } 36 \text { cryo, } 29 \text { RFA. }\end{array}$ & $\begin{array}{l}\text { eGFR change less with cryo and RFA. } \\
5.6 \% \text { required permanent dialysis after LPN. } \\
\text { Zero in ablative groups. } \\
\text { Disease-free survival better for LPN than } \\
\text { for cryo and RFA. }\end{array}$ \\
\hline Long $(2017)^{9}$ & $\begin{array}{l}284 \text { patients with imperative indication } \\
\text { (146 solitary). } \\
\text { Ablation (104 RFA, } 8 \text { cryo) vs. } 172 \mathrm{PN} \text {. }\end{array}$ & $\begin{array}{l}\text { No difference in eGFR change } \\
\text { (adjusted for complexity). } \\
\text { No difference in need for dialysis. } \\
\text { PN worse perioperative outcomes. } \\
\text { Recurrence-free survival better for PN } \\
\text { but met free recurrence similar. }\end{array}$ \\
\hline
\end{tabular}

LPN = laparoscopic partial nephrectomy; PCA = Percutaneous Cryoablation; RFA = radiofrequency ablation.

comparable perioperative and renal function outcomes between RPN and LARC in their series of 103 patients (47 RPN, 56 LARC) and thus argued that even comorbid patients can be offered RPN. ${ }^{24}$ However, one must consider their own small but recognized risk of conversion to radical nephrectomy due to uncontrolled bleeding (4.3\%), a catastrophic complication in a solitary kidney.

To the best of our knowledge, our study is the largest series of laparoscopy-assisted cryoablation in a solitary kidney to date. Previously published literature for cryoablation in solitary kidneys (laparoscopic or image-guided) is restricted to small case series or larger studies with significant heterogeneity in the energy modality utilized. We have shown that the decline in renal function after LARC in a solitary kidney is rarely of any clinical significance, despite showing a small statistical difference in eGFR. More importantly, no patient required any form of renal replacement therapy.

The main advantages of our study are that our renal function data were prospectively collected and examine a population with a solitary kidney, which is more likely to give a true reflection of the amount of nephron loss. Our null hypothesis was that cryoablation preserves kidney function with no significant change in pre- and post-treatment CKD stages. There was a small difference; however, this fell short of statistical significance (paired two-tailed $t$-test, $p=0.057$, NS). The overall complication and transfusion rates for our series were reasonable and acceptable, especially considering that many patients were high risk.
Several studies have attempted to retrospectively compare PN and ablative therapies for solitary kidneys (Table 5). All studies are of a retrospective nature and carry significant limitations. In particular, there is heterogeneity in ablative modalities and reporting. Oncologic outcomes tend to favor $\mathrm{PN}$; however, results are comparable and acceptable for cryotherapy. Overall, survival data are further biased against ablative therapies due to inherent patient selection bias. Turna and associates, in their solitary kidney series, reported a cancer-specific and overall survival at 2 years of $100 \%$ and $91.2 \%$ for LPN, $88.5 \%$ and $88.5 \%$ for cryoablation, and $83.9 \%$ and $83.9 \%$ for RFA, respectively. ${ }^{25}$ Our much larger series show comparable cancer-specific survival of $93 \%$ and the overall survival of $87.5 \%$ with a longer period of follow-up.

There are several limitations to this article. This is a nonrandomized noncomparative analysis. The multicenter nature of our database resulted in variations in surgical approaches and patient selection. Our database was established to collect data pertaining to the laparoscopic approach at a time where this was more commonly offered to patients in our participating centers. Thanks to improved techniques to allow for safe energy delivery and minimally invasive nature, percutaneous image-guided approaches have gained popularity and become the preferred treatment approach. However, this study makes the important point of demonstrating that there is no clinically significant deterioration in renal function necessitating any form of renal 
replacement. Future studies should compare newer imageguided techniques and robot-assisted PN.

\section{Conclusion}

To the best of our knowledge, this is the largest series of cryotherapy in SRMs in solitary kidneys to investigate renal function. It is clear from this study that although there is a small fall in eGFR in the postprocedure period, this does not have a clinical bearing and did not lead to renal replacement therapy. Although larger prospective randomized studies would enable more definitive conclusions, they are impractical in this relatively rare and clinically challenging group of patients. Our study demonstrates that LARC is a practical and safe treatment option.

\section{Author Disclosure Statement}

No competing financial interests exist.

\section{Funding Information}

No funding was received for this article.

\section{References}

1. Lee CT, Katz J, Shi W, Thaler HT, Reuter VE, Russo P. Surgical management of renal tumors $4 \mathrm{~cm}$. or less in a contemporary cohort. J Urol 2000;163:730-736.

2. Ljungberg B, Bensalah K, Canfield S, Dabestani S, Hofmann F, Hora M, et al. EAU guidelines on renal cell carcinoma: 2014 update. Eur Urol 2015;67:913-924.

3. McKiernan J, Simmons R, Katz J, Russo P. Natural history of chronic renal insufficiency after partial and radical nephrectomy. Urology 2002;59:816-820.

4. Kalogirou C, Fender H, Muck P, Hey V, Krebs M, Riedmiller $\mathrm{H}$, et al. Long-term outcome of nephron-sparing surgery compared to radical nephrectomy for renal cell carcinoma $\geq 4 \mathrm{~cm}-\mathrm{A}$ matched-pair single institution analysis. Urol Int 2017;98:138-147.

5. Gill IS, Kavoussi LR, Lane BR, Blute ML, Babineau D, Colombo JR, et al. Comparison of 1,800 laparoscopic and open partial nephrectomies for single renal tumors. J Urol 2007; 178:41-46.

6. Nielsen TK, Lagerveld BW, Keeley F, Lughezzani G, Sriprasad S, Barber NJ, et al. Oncological outcomes and complication rates after laparoscopic-assisted cryoablation: A European Registry for Renal Cryoablation (EuRECA) multi-institutional study. BJU Int 2017;119:390-395.

7. Zargar H, Autorino R, Kaouk JH. Nephron-sparing surgery for tumors in a solitary kidney. Curr Opin Urol 2014;24: 459-465.

8. Khan F, Mahmalji W, Madaan S, Dickinson IK, Keeley FX, Lagerveld BW SS. Multi-institutional analysis of renal function following cryoablation of small renal masses in solitary kidneys. BJU Int 2013;111:37.

9. Long J-A, Bernhard J-C, Bigot P, Lanchon C, Paparel P, Rioux-Leclercq N, et al. Partial nephrectomy versus ablative therapy for the treatment of renal tumors in an imperative setting. World J Urol 2017;35:649-656.

10. Stevens PE, Levin A, Kidney Disease: Improving Global Outcomes Chronic Kidney Disease Guideline Development Work Group Members. Evaluation and management of chronic kidney disease: Synopsis of the kidney disease-
Improving global outcomes 2012 clinical practice guideline. Ann Intern Med 2013;158:825.

11. Choi JD, Park JW, Choi JY, Kim HS, Jeong BC, Jeon SS, et al. Renal damage caused by warm ischaemia during laparoscopic and robot-assisted partial nephrectomy: An assessment using Tc 99m-DTPA glomerular filtration rate. Eur Urol 2010;58:900-905.

12. Becker F, Van Poppel H, Hakenberg OW, Stief C, Gill I, Guazzoni $\mathrm{G}$, et al. Assessing the impact of ischaemia time during partial nephrectomy. Eur Urol 2009;56:625635.

13. Esen T. Editorial comment on: Assessing the impact of ischaemia time during partial nephrectomy. Eur Urol 2009; 56:634-635.

14. Kim SH, Joung JY, Seo HK, Lee KH, Chung J. Baseline chronic kidney disease and ischemic method of partial nephrectomy are important factors for the short- and longterm deterioration in renal function for renal cell carcinoma staged T1-T2: A retrospective single center study. Biomed Res Int 2016;2016:1-8.

15. Thompson RH, Lane BR, Lohse CM, Leibovich BC, Fergany A, Frank I, et al. Every minute counts when the renal hilum is clamped during partial nephrectomy. Eur Urol 2010;58:340-345.

16. Sharma N, O'Hara J, Novick AC, Lieber M, Remer EM, Herts BR. Correlation between loss of renal function and loss of renal volume after partial nephrectomy for tumor in a solitary kidney. J Urol 2008;179:1284-1288.

17. Woldu SL, Thoreson GR, Okhunov Z, Ghandour R, Rothberg MB, RoyChoudhury A, et al. Comparison of renal parenchymal volume preservation between partial nephrectomy, cryoablation, and radiofrequency ablation using 3D volume measurements. J Endourol 2015;29:948955.

18. Faddegon S, Cadeddu JA. Does renal mass ablation provide adequate long-term oncologic control? Urol Clin North Am 2012;39:181-190.

19. Rivero JR, De La Cerda J, Wang H, Liss MA, Farrell AM, Rodriguez R, et al. Partial nephrectomy versus thermal ablation for clinical stage T1 renal masses: Systematic review and meta-analysis of more than 3,900 patients. J Vasc Interv Radiol 2018;29:18-29.

20. Olweny EO, Park SK, Tan YK, Best SL, Trimmer C, Cadeddu JA. Radiofrequency ablation versus partial nephrectomy in patients with solitary clinical T1a renal cell carcinoma: Comparable oncologic outcomes at a minimum of 5 years of follow-up. Eur Urol 2012;61:11561161.

21. Klatte T, Grubmüller B, Waldert M, Weibl P, Remzi M. Laparoscopic cryoablation versus partial nephrectomy for the treatment of small renal masses: Systematic review and cumulative analysis of observational studies. Eur Urol 2011;60:435-443.

22. Pantelidou M, Challacombe B, McGrath A, Brown M, Ilyas $\mathrm{S}$, Katsanos K, et al. Percutaneous radiofrequency ablation versus robotic-assisted partial nephrectomy for the treatment of small renal cell carcinoma. Cardiovasc Intervent Radiol 2016;39:1595-1603.

23. Thompson RH, Atwell T, Schmit G, Lohse CM, Kurup AN, Weisbrod A, et al. Comparison of partial nephrectomy and percutaneous ablation for cT1 renal masses. Eur Urol 2015; 67:252-259.

24. Emara AM, Kommu SS, Hindley RG, Barber NJ. Robotassisted partial nephrectomy vs laparoscopic cryoablation 
for the small renal mass: Redefining the minimally invasive 'gold standard.' BJU Int 2014;113:92-99.

25. Turna B, Kaouk JH, Frota R, Stein RJ, Kamoi K, Gill IS, et al. Minimally invasive nephron sparing management for renal tumors in solitary kidneys. J Urol 2009;182:2150-2157.

26. Ghoneim TP, Sjoberg DD, Lowrance W, Shariat SF, Savage C, Bernstein M, et al. Partial nephrectomy for renal tumors in solitary kidneys: postoperative renal function dynamics. World J Urol 2015;33:2023-2029.

27. Kitrey ND, Djakovic N, Kuehhas FE, Lumen N, Serafetinidis E, Sharma DM. EAU Guidelines on Urological Trauma. Present EAU Annu Congr Copenhagen. Available from: http://uroweb.org/wp-content/uploads/EAU-Guidelineson-Urological-Trauma-2018-large-text.pdf (Accessed April 14, 2018)

28. Ching CB, Lane BR, Campbell SC, Li J, Fergany AF. Five to 10-Year Followup of Open Partial Nephrectomy in a Solitary Kidney. J Urol 2013;190:470-474.

29. Bhindi B, Mason RJ, Haddad MM, Boorjian SA, Leibovich BC, Atwell TD, et al. Outcomes After Cryoablation Versus Partial Nephrectomy for Sporadic Renal Tumors in a Solitary Kidney: A Propensity Score Analysis. Eur Urol 2018; 73:254-259.

30. Mues AC, Korets R, Graversen JA, Badani KK, Bird VG, Best SL, et al. Clinical, pathologic, and functional outcomes after nephron-sparing surgery in patients with a solitary kidney: a multicenter experience. J Endourol 2012;26:1361-1366.

31. Panumatrassamee K, Kaouk JH, Autorino R, Lenis AT, Laydner H, Isac W, et al. Cryoablation Versus Minimally Invasive Partial Nephrectomy for Small Renal Masses in the Solitary Kidney: Impact of Approach on Functional Outcomes. J Urol 2013;189:818-822.
Address correspondence to: Mohammed Aldiwani, MBChB, MSc, MRCS Department of Urology Darent Valley Hospital

Dartford DA3 7RA

United Kingdom

E-mail: mohammed.aldiwani@doctors.org.uk

$\begin{aligned} & \text { Abbreviations Used } \\ \mathrm{AKI} & =\text { acute kidney injury } \\ \mathrm{ASA} & =\text { American Society of Anesthesiologists } \\ \mathrm{BMI} & =\text { body mass index } \\ \mathrm{CI} & =\text { confidence interval } \\ \mathrm{CKD} & =\text { chronic kidney disease } \\ \mathrm{EAU} & =\text { European Association of Urology } \\ \mathrm{eGFR} & =\text { estimated glomerular filtration rate } \\ \text { EuRECA } & =\text { European Registry for Renal Cryoablation } \\ \mathrm{IQR} & =\text { interquartile range } \\ \mathrm{LARC} & =\text { laparoscopy-assisted renal cryoablation } \\ \mathrm{LPN} & =\text { laparoscopic partial nephrectomy } \\ \mathrm{NS} & =\text { not significant } \\ \mathrm{PCA} & =\text { Percutaneous Cryoablation } \\ \mathrm{PN} & =\text { partial nephrectomy } \\ \mathrm{RFA} & =\text { radiofrequency ablation } \\ \mathrm{RPN} & =\text { robotic partial nephrectomy } \\ \mathrm{RPV} & =\text { renal parenchymal volume } \\ \mathrm{SD} & =\text { standard deviation } \\ \mathrm{SRMS} & =\text { small renal masses } \\ \mathrm{WIT} & =\text { warm ischemia time }\end{aligned}$

